\title{
Nieznane kijowskie materiały do biografii generała Jurija Tiutiunnyka
}

Юрій Тютюнник: від «Двійки» до ППУ. Документи і матеріали, упоряд. В. Верстюк, В. Скальський, Я. Файзулін, Київ 2011, ss. 596

$\mathrm{P}$ od koniec 2011 r. nakładem kijowskiego wydawnictwa „Duch i Litera” ukazała się bardzo interesująca edycja źródeł. Została ona poświęcona jednej z najbarwniejszych postaci ukraińskiego ruchu niepodległościowego początku XX w. - generałowi Jurijowi Tiutiunnykowi. Publikacja była możliwa dzięki temu, że zgodnie z rozporządzeniem prezydenta Ukrainy z 2009 r., część swoich zbiorów upubliczniło Resortowe Archiwum Państwowe Służby Wywiadu Zewnętrznego Ukrainy w Kijowie (Галузевий державний архів Служби зовнішньої розвідки України) $)^{1}$. Instytucja ta, wraz z Resortowym Archiwum Państwowym Służby Bezpieczeństwa Ukrainy w Kijowie (Галузевий державний архів Служби безпеки України), odziedziczyła spuściznę po archiwach sowieckich służb bezpieczeństwa i dotąd w zasadzie nie udostępniała swoich zbiorów historykom.

Postać generała Jurija Tiutiunnyka jest bardzo ciekawa. W Polsce to osoba mało znana, w historiografii pojawia się rzadko, i to właściwie jedynie przy okazji wzmianek na temat tzw. drugiego pochodu zimowego czy inaczej listopadowego rajdu armii Ukraińskiej Republiki Ludowej (URL) z 1921 r. We współczesnej historiografii ukraińskiej Jurko Tiutiunnyk jest

\footnotetext{
${ }^{1}$ Obszerniej o udostępnieniu niektórych materiałów przez to archiwum: Ю. В. Котляр, Ю. Тютюнник у матеріалах Галузевого державного архіву Служби зовнішньої розвідки України, „Історичний архів. Наукові студії”, 2011, вип. 7, s. 103-106.
} 
obecny i przedstawiany jako nieugięty bohater walczący w latach 1917-1921 o niepodległość Ukrainy. Generał ukraińskiej armii, wspaniały partyzant, niezwykle popularny wśród ukraińskiego ludu. Człowiek, który po podpisaniu preliminariów pokojowych nie złożył broni, podstępnie zwabiony na sowiecką Ukrainę, został zmuszony do współpracy z dotychczasowym wrogiem, co i tak nie uchroniło go od śmierci z rąk OGPU. Z grubsza taki bohaterski obraz generała wyłania się z jego publikowanych biografii ${ }^{2}$. Jednak analizując zachowane materiały źródłowe, można dojść do wniosku, że działalność generała Tiutiunnyka może budzić spore kontrowersje.

Jurij Tiutiunnyk urodził się w 1891 r. we wsi Budyszczi na Kijowszczyźnie. Po ukończeniu szkoły rolniczej w Humaniu został w 1913 r. powołany do wojska. Służył w 6. Syberyjskim Pułku Strzeleckim, w szeregach którego zastał go wybuch I wojny światowej. Podczas działań wojennych był dwukrotnie ranny, a w 1915 r. ukończył Tyfliską Szkołę Wojskową (czasu wojny). Od 1916 r. służył w 32. Zapasowym Pułku Piechoty w Symferopolu. Służbę w armii rosyjskiej zakończył w stopniu chorążego (wówczas pierwszy stopień oficerski). W 1917 r. zaangażował się w ukrainizację armii rosyjskiej i działalność polityczną. Został m.in. członkiem Centralnej Rady - czyli ukraińskiego ciała ustawodawczego, które proklamowało utworzenie Ukraińskiej Republiki Ludowej. W styczniu 1918 r. w swoich stronach rodzinnych działał na rzecz utworzenia tzw. Wolnego Kozactwa. $\mathrm{Na}$ czele lokalnych oddziałów brał udział w rozbrajaniu powracających $\mathrm{z}$ frontu zbolszewizowanych oddziałów rosyjskich. Po utworzeniu Państwa Ukraińskiego hetmana Pawła Skoropadskiego aktywnie przeciwko niemu występował, będąc jednym z przywódców tzw. Powstania Zwenyhorodsko-Taraszczanskiego. Został przez władze hetmańskie aresztowany i uwięziony w Kijowie, gdzie w grudniu 1918 r. na fali antyhetmańskiego powstania zorganizował udany bunt więźniów, czym przyczynił się do opanowania Kijowa przez wojska Dyrektoriatu. Tiutiunnyk nie chciał jednak współpracować z nowymi władzami Ukraińskiej Republiki Ludowej i związał się z tzw. borotbistami, czyli lewym skrzydłem ukraińskich eserów. Od lutego 1919 r. był szefem sztabu dowodzonej przez atamana Hryhoriewa I Brygady 1. Zadnieprzańskiej Dywizji Robotniczo-Chłopskiej Armii Czerwonej. Na-

2 Zob. choćby: Генералітет украӥнських визвольних змагань, ред. О. Колянчук, М. Литвин, К. Науменко, Львів 1995, s. 254-256; О. Шатайло, Генерал Юрко Тютюнник, Львів 2000; Я. Тинченко, Офічерский корпус Армї̈ Украӥнської Народної Республіки (1917-1921), Книга 1, Київ 2007, s. 446-447. 
stępnie, będąc komendantem Odessy i dowódcą I Brygady 6. Sowieckiej Dywizji Ukraińskiej, stanął po stronie Hryhoriewa, gdy ten zbuntował się przeciwko władzy bolszewickiej. Od maja 1919 r., po stłumieniu powstania Hryhoriewa, prowadził z powodzeniem działania partyzanckie, przyłączając się ostatecznie do sił zbrojnych Ukraińskiej Republiki Ludowej.

W lipcu 1919 r. oddział Tiutiunnyka przemianowano na dowodzoną przez niego i składającą się z dwóch dywizji Grupę Kijowską, wchodzącą w skład Armii Czynnej URL. Był zastępcą dowódcy i prawdopodobnie faktycznym dowódcą tzw. pierwszego pochodu zimowego wojsk URL na tyły armii Denikina, a następnie bolszewickie. W 1920 r. Jurij Tiutiunnyk pełnił funkcję dowódcy 4. Dywizji Kijowskiej, został też mianowany generałem-chorunżym armii URL. Jesienią tego roku, po przejściu armii ukraińskiej na tereny zajmowane przez Wojsko Polskie, próbował na własną rękę prowadzić walkę partyzancką przeciwko bolszewikom. Ostatecznie został internowany w Polsce i przebywał m.in. w obozie internowanych w Aleksandrowie Kujawskim. W 1921 r. został organizatorem i szefem tzw. Sztabu Powstańczo-Partyzanckiego. Ta zakonspirowana struktura działała w Polsce przy akceptacji polskich władz wojskowych. Jej zadaniem miało być przygotowanie odpowiednich kadr oraz zaplanowanie i wywołanie ogólnego powstania przeciwko bolszewickim władzom na Ukrainie. Sygnałem do działania miał być rajd dowodzonych przez generała Tiutiunnyka oddziałów na tereny sowieckiej Ukrainy, który odbył się w listopadzie 1921 r. Przedsięwzięcie to zakończyło się całkowitą klęską, przy czym strona ukraińska (a co za tym idzie - także ukraińska historiografia) odpowiedzialnością za niepowodzenie obarczyła polskie służby, które miały nie wywiązać się z obietnic zapewnienia odpowiedniego wsparcia materialnego powstańcom.

W 1923 r. generał Jurij Tiutiunnyk powrócił na sowiecką Ukrainę i rozpoczął współpracę z tamtejszymi władzami. Wykładał w charkowskiej Szkole Czerwonych Dowódców, pisał wspomnienia, scenariusze do filmów, a w jednym z nich zagrał nawet samego siebie. Był to film pod tytułem $P K P$, czyli Pitsudskyj kupyw Peluru. W 1929 r. Tiutiunnyk został aresztowany przez organy OGPU, a 20 października 1930 r. rozstrzelany.

Omawiana publikacja źródłowa dotyczy działalności generała po klęsce tzw. drugiego pochodu zimowego. Książka składa się ze wstępu i sześciu rozdziałów. Jest zaopatrzona w wykaz opublikowanych dokumentów, indeks osób i indeks geograficzny, a także streszczenie i spis treści w języku polskim. W liczącym 14 stron wstępie jego autor Władysław Werstiuk omówił 
stan zachowania źródeł dotyczących Jurija Tiutiunnyka, a udostępnionych przez Resortowe Archiwum Państwowe Służby Wywiadu Zewnętrznego Ukrainy. Poza tym autor nakreślił główne wątki aktywności generała w świetle publikowanych materiałów. Pierwszy rozdział nosi tytuł „Listy Jurija Tiutiunnyka z okresu jego pobytu na terytorium Polski (1921-pierwsza połowa 1923)". Mimo to w rozdziale tym nie znalazł się żaden list z $1921 \mathrm{r}$. Korespondencja jest uporządkowana chronologicznie, a najstarszy list nosi datę 12 lipca 1922 r. Rozdział drugi jest zatytułowany „Listy do Jurija Tiutiunnyka z okresu jego pobytu na terytorium Polski (1921-pierwsza połowa 1923)". Także w tym przypadku najstarszy publikowany list jest nie z roku 1921, a z 14 maja 1922 r. W podobnej konwencji są utrzymane rozdziały trzeci i czwarty, lecz zawierają listy generała (rozdział trzeci) i korespondencję do niego adresowaną (rozdział czwarty) z okresu jego „uprowadzenia” do USSR (druga połowa roku 1923 do roku 1929). Większość korespondencji zawartej w tych rozdziałach dotyczy jednak lat 1923-1926 i tylko nieliczne listy powstały w latach późniejszych. W sumie w czterech pierwszych rozdziałach publikacji zamieszczono ogromną spuściznę epistolarną generała Tiutiunnyka, liczącą w sumie 433 listy. Wszystkie publikowane listy w oryginale są przechowywane we wspomnianym wyżej Archiwum Służby Wywiadu Zewnętrznego. Świetnym uzupełnieniem publikowanych źródeł epistolarnych jest zamieszczony w rozdziale piątym „Wyciag ze sprawy operacyjnej prowadzonej przez organa Komisariatu Ludowego Państwowego Zarządu Politycznego (GPU) Ukrainy w latach 1921-1923 w celu «uprowadzenia» generała armii URL, Jurija Tiutiunnyka". Materiał ten pochodzi z Resortowego Archiwum Państwowego Służby Bezpieczeństwa Ukrainy. Rozdział szósty to niepublikowany wcześniej, ciekawy artykuł autorstwa Ołeksija Kobcia zatytułowany „Wertajteś do domu (istorija doli J. Tiutiunnyka)". Ten tekst w oryginale jest przechowywany w Archiwum Ukraińskiej Wolnej Akademii Nauk w Winnipeg (Kanada).

Omawiana publikacja źródłowa zawiera bardzo cenny, interesujący i dotychczas nieznany historykom materiał, który rzuca nowe światło na działalność generała Tiutiunnyka. Zwłaszcza na kontrowersyjną i dotąd nie do końca wyjaśnioną sprawę jego powrotu na sowiecką Ukrainę. Dotychczas badacze dysponowali jedynie dokumentami związanymi z Tiutiunnykiem oraz kierowanym przez niego Sztabem Powstańczo-Partyzanckim z lat 1920-1921 przechowywanymi w Bibliotece Narodowej w Warszawie, w zespole nazwanym „Archiwum im. Tarasa Szewczenki”. Ciekawe źródła do biografii generała są także dostępne w Centralnym Państwowym Archiwum 
Organizacji Społecznych Ukrainy w Kijowie (Центральний державний архів громадських об'єднань України) ${ }^{3}$. Gruntowne i wszechstronne przebadanie tego materiału źródłowego uzupełnione analizą literatury wspomnieniowej, zwłaszcza autorstwa samego Tiutiunnyka ${ }^{4}$, może zaowocować powstaniem solidnego opracowania biograficznego poświęconego tej barwnej, kontrowersyjnej i tragicznej postaci.

Maciej Krotofil

DOI: http://dx.doi.org/10.12775/EO.2012.011

\section{Bitwa pod Gorlicami w 1915 r.}

Richard L. DiNardo, Przełom. Bitwa pod Gorlicami-Tarnowem 1915*, Warszawa 2012, ss. 271

\siążka Richarda L. DiNardo poświęcona działaniom na froncie wschodLnim ukazała się w 2012 r. nakładem wydawnictwa „Rebis”. Tłumaczenia dokonał Jan Szkudliński, naukowo zajmujący się frontem wschodnim I wojny światowej, a redakcji merytorycznej prof. dr hab. Tomasz Schramm. Autor dotychczas nie zajmował się ani I wojną światową, ani tym bardziej jej frontem wschodnim. Znany jest m.in. z biografii konfederackiego generała, Jamesa Longstreeta ${ }^{5}$, czy z publikacji dotyczących II wojny światowej ${ }^{6}$.

3 Zwłaszcza w zespole nr 5 Комиссия по истории гражданской войны при Центральном комитете коммунистической партии (большевиков) Украины 1917-1938 гг.

${ }_{4}^{4}$ Zob. choćby: Ю. Тютюнник, Зимовий похід 1919-20 pp., Коломия-Київ 1923; idem, 3 поляками проти Вкрайни, Харків 1924; idem, Рєволючійна стихія, Львів 1937; О. Божко, Генерал-хорунжий Армії УНР. Невідома автобіографія Ю. Тютюнника, „3 архівів ВУЧК-ГПУ-НКВД-КГБ”, 1998, № 1-2, s. 24-56.

* Tytuł oryginalny: Breakthrough. The Gorlice-Tarnow Campaign 1915 - widać zatem, że tłumacz dokonał korekty tytułu, gdyż termin „kampania gorlicko-tarnowska” nie funkcjonuje w żadnych źródłach ani też w naukowej literaturze niemieckiej czy rosyjskiej. Zob. J. Centek, Bitwa pod Gorlicami, Mate Verdun czy Operacja Tarnowsko-Gorlicka. Regionalna polityka historyczna, [w:] Materiaty z międzynarodowej konferencji naukowej Znaki Pamięci V-bitwa gorlicka, jej znaczenie i skutki, red. K. Ruszała, Gorlice 2012, s. 5-14.

${ }_{5}$ R. L. DiNardo, James Longstreet: The Man, the Soldier, the Controversy, Conshohocken 1998.

${ }^{6}$ Idem, Germany's Panzer Arm in World War II, Mechanicsburg 1997; idem, Germany and the Axis Powers: From Coalition to Collapse, Lawrence 2005. 